week 8 or to a matched placebo in addition to their existing analgesic or non-steroidal anti-inflammatory regimen. Treatment was continued for a six-month period with monthly assessments. We found no improvement in the clinical parameters measured (night pain, early morning stiffness, articular index, functional impairment, pain on walking, pain at rest, or range of movement) in the penicillamine-treated group compared with the placebo group. Eight of these patients (four on active treatment and four on placebo) had raised erythrocyte sedimentation rates (ESRs) at the start of the study, and no improvement was seen in the ESR in either group. Three patients withdrew from the penicillamine-treated group because of accepted side effects from this drug. Blind analysis of $x$-rays taken at the start and end of the study showed no serial improvement for either group over this six-month period. Although the number of patients studied was extremely small, we found no evidence from this pilot study that penicillamine might be worthy of larger and more labour-intensive trials in osteoarthrosis.

Clinical Pharmacology Unit,

Royal Bath Hospital,

Harrogate and

General Infirmary,

Leeds

\section{Antibodies to peptidoglycan in spondylarthritis?}

SIR, We read with interest the study of Park et al. ${ }^{1}$ showing some association between serum antibody to bacterial peptidoglycan (PG) and both ankylosing spondylitis (AS) and Reiter's syndrome (RS), but surprisingly no such association with rheumatoid arthritis (RA). Antibody levels were measured by enzyme-linked immunosorbent assay (ELISA) with a synthetic PG as antigen, which consisted of PG-precursor pentapeptides (L-Ala- $\gamma-D-G l n-$ L-Lys-D-Ala-D-Ala) covalently linked to a random polypeptide. This pentapeptide is similar to that found commonly in PG of Gram-positive bacteria, whereas the PG of Gram-negative bacteria has a different structure containing diaminopimelic acid (DAP) in a peptide ( $\mathrm{L}-\mathrm{Ala}$ $\gamma$-D-GIn-meso-DAP-D-Ala-D-Ala) or similar peptide sequence together with different cross linking. Furthermore. PG is not such a prominent antigen in Gram-negative organisms as is the case for Gram-positive bacteria. For example, we find that rabbit antisera raised against isolated Gram-positive PG react only poorly or not at all with most Gram-negative bacteria, including klebsiella, unlike their consistently strong reaction with most Grampositive bacteria.

An ELISA has been developed in this laboratory for antibodies reactive with peptidoglycan-polysaccharicie polymers (PG-PS) isolated from Gram-positive group A Streptococcus pyogenes cell walls. ${ }^{2}$ A significantly increased prevalence $(\mathrm{p}<0.005)$ of serum anti-PG-PS antibody was found in juvenile chronic arthritis $(70 \%$ of patients had anti-PG-PS levels above the upper limit of the normal range), seropositive RA (46\%), and seronegative RA (50\%), compared with AS, systemic lupus erythematosus, myeloma, and healthy controls. ${ }^{2}$ In a separate study, in collaboration with $\operatorname{Dr} \mathrm{A}$. Ebringer, it was found that only $6 \%$ of patients with either active $(n=40)$ or inactive $(n=50)$ AS had anti-PG-PS serum antibody levels raised above normal limits (unpublished data).

We suggest that the weak associations between anti-PG antibody levels and both AS and RS observed by Park et $a l .{ }^{\prime}$ may be due to unrelated infections with Gram-positive bacteria and that these data provide no relevant information on immunity to Gram-negative bacteria, such as klebsiella, shigella, and yersinia.

Departments of Immunology,

H B EVANS Medical Microbiology,

and Microbiology,

University of Liverpool

M JOHNSON

K K PHUA

C A HART

PO Box 147.

H R PERKINS

Liverpool L69 3BX

\section{References}

1 Park H. Schumacher H R. Zeiger A R. Rosenbaum J T. Antibodies to peptidoglycan in patients with spondylarthritis: a clue to disease aetiology? Ann Rheum Dis 1984; 43: 725-8.

2 Johnson P M. Phua K K. Perkins H R. Hart C A. Bucknall R C. Antibody to streptococcal cell wall peptidoglycanpolysaccharide polymers in seropositive and seronegative rheumatic disease. Clin Exp Immunol 1984; 55: 115-24.

SiR, We thank Evans et al. for their letter and the editor for giving us the opportunity to respond. Their suggestion that the weak associations between anti-PG antibody levels and both AS and RS may be due to 'unrelated infections' with Gram-positive bacteria may or may not be correct. The cause(s) of the rheumatic diseases, such as AS, RS, and $\mathrm{RA}$, is not known. Moreover, the antibodies that we measured' could have developed from an immune response to Gram-positive (or even possibly Gram-negative) bacteria at various sites, including normal flora. Our recent report ${ }^{2}$ of soluble forms of $\mathrm{PG}$ present in the urine samples of healthy volunteers who had taken an oral dose of penicillin suggests that the bacteria responsible for the PG-like antigen in humans may not necessarily be engaged in infections.

The discrepancies that exist in the literature on the association of anti-PG antibodies with several diseases (some of which were mentioned in the Discussion ${ }^{1}$ ), may have arisen from differences in populations studied (bacterial colonisation and genetic make up), treatments administered (antibiotics), and assays employed. The antibodies measured in our study ${ }^{1}$ were specifically directed against the major determinant of the PG, the $D-A l a-D-A l a ~ s e q u e n c e$, because we used a synthetic PG precursor pentapeptide (Ala- $\gamma$-D-Glu-Lys-D-Ala-D-Ala) as the antigen and a synthetic tripeptide ( $\alpha$-Boc-Lys-D-Ala-DAla) as a specific antibody inhibitor. ' The antibodies measured by Johnson et al. ${ }^{3}$ had a different and more complex specificity. Their anti-PG-PS antibodies found in RA sera were not significantly inhibited by two tripeptides 
containing the D-Ala-D-Ala sequence. ${ }^{3}$ Therefore the apparent discrepancy between our results and theirs in RA sera is not surprising. Furthermore we are not alone in failing to note an association between serum antibody to bacterial PG and RA. Pope et al. have recently made a similar observation. ${ }^{4}$

There is, however, one point on which all studies of anti-PG concur; namely, that the humoral immune response to bacterial PG in humans is diverse. Until the basis for this diversity is more clearly understood, the relationship of anti-PG to rheumatic diseases, such as AS, RS, and RA, will probably remain a matter of speculation.

Rheumatology-Immunology Center,

Veierans Administration

Medical Center,

Philadelphia, PA,

USA

Department of Biochemistry,

A R ZEIGER

Thomas Jefferson University,

Philadelphia, PA,

USA

Kuzell Institute for Arthritis Research, J I ROSENBAUM Medical Research Institute,

San Francisco, CA,

USA

\section{References}

1 Park H, Schumacher H R, Zeiger A R, Rosenbaum J T. Antibodies to peptidoglycan in patients with spondylarthritis: a clue to disease aetiology? Ann Rheum Dis 1984; 43: 725-8.

2 Park H, Zeiger A R, Schumacher H R. Detection of soluble peptidoglycan in urine after penicillin administration. Infect Immun 1984; 43: 139-42.

3 Johnson P M, Phua K K, Perkins H R, Hart C A, Bucknall R C. Antibody to streptococcal cell wall peptidoglycanpolysaccharide polymers in seropositive and seronegative rheumatic disease. Clin Exp Immunol 1984; 55: 115-24.

4 Pope R M, Rutstein J E, Straus D C. Detection of antibodies to streptococcal mucopeptide in patients with rheumatic disorders and normal controls. Int Arch Allergy Appl Immunol 1982; 62: 267-74.

\section{Blood dyscrasia associated with azapropazone therapy}

SIR, The pyrazolon derivatives phenylbutazone and oxyphenbutazone are potent causes of blood dyscrasias, ${ }^{1}{ }^{2}$ but azapropazone, a pyrazolon derivative ${ }^{1}$ in regular usage, has been considered to be free of haematological side effects. ${ }^{2}$ In May 1984 an 80-year-old female was admitted for investigation of leucopenia and anaemia which had? developed five weeks after commencing azapropazone $300 \mathrm{mg}$ four times a day. Her other medications consisted? of thyroxine $0.15 \mathrm{mg}$ in the morning, ferrous sulphate $20 \mathrm{~g}$ mg three times daily, and lactulose $15 \mathrm{ml}$ twice daily믐 Significant medical history consisted of primary hypo $\frac{\bar{S}}{\sqrt{5}}$ thyroidism (diagnosed in 1977), adenocarcinoma of the colon treated by anterior resection in 1979 and, in 1980 o investigation of mild asymptomatic splenomegaly. Bones marrow smears analysed in 1980 were consistent witb involvement by early chronic lymphatic leukaemia withsatisfactory granulocyte maturation. At a follow up i $\vec{\omega}$ March 1984 haemoglobin was $9.9 \mathrm{~g} / \mathrm{dl}$, red cells $3.52 \times$ $10^{12} / 1$, white cells $4.1 \times 10^{9} / 1$, and platelets $185 \times 10^{9} / 1$. I莡 May 1984 haemoglobin was $6.9 \mathrm{~g} / \mathrm{dl}$, red cells $2.49 \times 10^{12} / \mathrm{l}_{\mathrm{A}}^{.}$ white cells $0.6 \times 10^{9} / 1$ (neutrophils $79 \%$, eosinophils $0 \%$ basophils $0 \%$, lymphocytes $20 \%$, monocytes $1 \%$ ), anf platelets $121 \times 10^{9} / 1$. The blood film showed mature whit@ cells and a normochromic anaemia with marked aniso -7 poikilocytosis; the bone marrow showed dyserythroblastio and dysmyeloblastic features with no evidence of carcin=oma, and the granulocyte series was arrested at the myelocyte stage. Chest $x$-ray, serum $\mathrm{B} 12$ and folate repeated faecal occult blood tests, and blood and urine cultures were unremarkable. Blood urea was 9.3 mmoldo and creatinine $151 \mu \mathrm{mol} / \mathrm{l}$. Azapropazone was withdrawn, and by 12 days postadmission white cells were $4.1 \times 10^{9} \mathrm{P}$ (neutrophils $81 \%$, eosinophils $2 \%$, basophils $1 \%$, lympho cytes $10 \%$, monocytes $6 \%$ ), haemoglobin $9.0 \mathrm{~g} / \mathrm{dl}$, an platelets $187 \times 10^{9} / 1$. She was discharged, and in Novemw ber 1984 haemoglobin was $12 \cdot 1 \mathrm{~g} / \mathrm{dl}$, red cells $3.93 \times 10^{12} / \mathrm{P}^{\circ}$ white cells $6 \cdot 1 \times 10^{9} / 1$, and platelets $213 \times 10^{9} / 1$.

This patient's underlying, albeit quiescent, haemopoietie problem may have rendered her more susceptible to drug-induced toxic effect, suggesting that it may be prudent to avoid azapropazone in such cases.

Division of Geriatric Medicine,

Stobhill General Hospital,

Glasgow G21 3UW

STEPHEN T GREE HUGH MCMILLAE LINDSAY ERWL

\section{References}

1 Flower R J, Moncada S, Vane J R. Analgesic-antipyretics and anti-inflammatory agents: drugs employed in the treatment gout. In: Gilman A G, Goodman L S, Goodman A, eds. T pharmacological basis of therapeutics. 6th ed. New YorE. Toronto, \& London: Macmillan, 1980: 682-728.

2 British Medical Association and Pharmaceutical Society 8 ? Great Britain. British national formulary no. 8. 1984: 306-1N

\section{Notes}

\section{EULAR symposium 1986}

A symposium on 'seronegative polyarthritis' will be held in Rome on 13-15 October 1986. Details from Professor Raffaele Numo, Cattedra di Reumatologia, Policlinico, 70124 Bari, Italy.

\section{XVth Symposium of the Europeagn Society of Osteoarthrology}

The symposium on 'Articular cartilage and other joint structures in relation to loading and movement' will bo held on 25-27 June 1986 in Kuopio, Finland. Details fro审 Heikki J Helminen, ScD(Med.), Managing Chairmapf University of Kuopio, Department of Anatomy, PO Bo\& 6, SF-70211 Kuopio, Finland. 